\section{ANALISIS PENERAPAN COST RECOVERY METHOD DAN PERCENTAGE OF COMPLETION METHOD BERDASARKAN PSAK 34 TERHADAP LABA KOTOR PERUSAHAAN PT MITRA MENARA MANDIRI}

\author{
Jhonatan dan Robert Pius Pardede
}

\author{
Program Studi Akuntansi \\ Sekolah Tinggi Ilmu Ekonomi Kesatuan Bogor, Indonesia \\ E-mail :lemlit@stiekesatuan.ac.id
}

\title{
ABSTRACK
}

Economic in Indonesia is growing rapidly. One of the supporting factors economic development in Indonesia is the construction field which is growing from year to year. The construction completion process carried out by a construction company has a different period of time depending on the request of the employer. The construction companies measure their gross profit by using the percentage settlement method or the recovered cost method depends on the contract. In general, the contractor company is still wrong in using these methods so that the company does not know clearly the gross profit obtained.

The purpose of this study was to determine the recognition of gross profit by applying the recoverable cost method and the percentage of completion method of PT Mitra Menara Mandiri and knowing the factors that influence the selection of methods in the recognition of gross profit using the percentage settlement method and the recoverable cost method at PT Mitra Menara Mandiri.

The results of the analysis of the implementation of the cost recovery method and the percentage settlement method of the company's gross profit at PT Mitra Menara Mandiri are still not in accordance with generally accepted accounting principles in terms of determining the recognition of the revenue applied. There is a weakness in the company in recording journals, such as the company does not record business journals when receiving a job and the company does not record if the company conducts billing terms. Therefore, the company should at the time of conducting the billing the company records the journal and records the accounts receivable journal at the time of receiving the job to avoid losing data at the time PT Mitra Menara Mandiri receives cash on the receivables that have been billed.

Keywords: PSAK 34, construction, recognition revenue

\section{PENDAHULUAN}

Pada saat ini perkembangan ekonomi di Indonesia sedang berkembang dengan pesat. Salah satu faktor pendukung perkembangan ekonomi di Indonesia yaitu di bidang kontruksi yang terus meningkat dari tahun ke tahun. Proses penyelesaian pembangunan yang dilakukan oleh perusahaan konstruksi memiliki jangka waktu yang berbeda-beda tergantung dari permintaan pemberi kerja dan pekerjaan apa yang akan dilaksanakan oleh penerima kerja (perusahaan konstruksi).

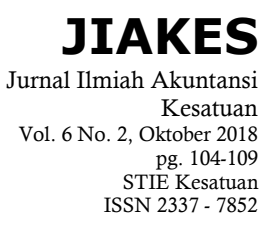

Submitted: MAY 2018 
Pada umumnya ada juga perusahaan kontrak kontruksi yang salah atau masih keliru dalam menggunakan metode persentase penyelesaian (percentage of completion method) dan metode biaya terpulihkan (cost recover method), sehingga perusahaan tersebut tidak mengetahui secara jelas apakah laba kotor yang diperoleh sudah benar atau tidak, untuk menjauhi dari ketidaktepatan dan ketidakakuratan maka harus sesuai dengan metode yang terdapat pada PSAK 34. Penerapan metode Cost Recovery Method dan Percentage Of Completion Method dilakukan tidak hanya untuk keakuratan dalam pengakuan pendapatan. Melihat laporan dalam suatu proyek merupakan salah faktor yang penting dalam perusahaan untuk menentukan laba kotor yang di perolehnya dengan baik dan dikatakan memenuhi standar dalam perusahaan kontrak kontruksi karena laporanlaporan tersebut adalah bukti tertulis suatu proyek.

Penulis menyimpulkan dengan pengakuan pendapatan yang tidak sesuai dengan Standar Akuntansi Keuangan maka akan mempengaruhi laporan laba atau rugi perusahaan. Selain itu pengakuan pendapatan yang tidak baik juga disebabkan oleh perusahaan tidak menggunakan metode persentase penyelesaian atau metode biaya terpulihkan yang sesuai dengan PSAK 34.

\section{TINJAUAN PUSTAKA}

\section{Pendapatan}

Definisi pendapatan menurut PSAK 23 (revisi 2010) adalah arus masuk kotor dari manfaat ekonomi yang timbul dari aktivitas normal entitas selama satu periode jika arus masuk tersebut mengakibatkan kenaikan ekuitas yang tidak berasak dari kontribusi penanam modal.

\section{Pengakuan Pendapatan}

Menurut Martani (2016,208) pendapatan di akui ketika besar kemungkinan bahwa manfaat ekonomi akan mengalir ke dalam perusahaan dan nilai manfaat tersebut dapat di ukur dengan andal. Untuk masing-masing jenis pendapatan, berikut adalah penjelasan mengenai saat kapan umumnya kedua kondisi tersebut terpenuhi untuk di akui sebagai pendapatan.

\section{Laba Kotor}

Menurut Stice $(2011,214)$ laba kotor adalah selisih antara pendapatan dari penjualan bersih dan harga pokok penjualan; persentase laba kotor, dihitung dengan membagi laba kotor dengan pendapatan bersih-menunjukan ukuran profitabilitas yang memungkinkan perbandingan perusahaan dari tahun ke tahun.

\section{Pengakuan pendapatan Kontrak}

Martani (2015, )Pengakuan pendapatan dengan mengacu pada tahap penyelesaian suatu transaksi sering kali disebut sebagai metode persentase penyelesaian. Berdasarkan metode ini, entitas mengakui pendapatan dalam periode akuntansi yang mana jasa diserahkan, yang menyediakan informasi bermanfaat pada besarnya kegiatan jasa dan kinerja selama satu periode. Tahap penyelesaian transaksi akan ditentukan oleh berbagai macam metode:

1. Survei atas pekerjaan yang telah dilakukan

2. Jasa yang dilakukan pada sampai saat persentase atas keseluruhan jasa telah dilakukan 
3. Biaya yang dikeluarkan hingga saat ini (hanya meliputi biaya-biaya yang mencerminkan jasa yang dilakukan hingga saat ini) sebagai persentase dari total biaya transaksi yang diestimasi (hanya meliputi biaya yang mencerminkan jasa yang dilakukan atau akan dilakukan)

\section{Metode Persentase Penyelesaian (Percentage of Completion Method)}

Martani (2015) Perusahaan harus menggunakan metode persentase penyelesaian ketika hasil kontrak kontruksi dapat diestimasi secara andal dan jika semua kondisi berikut terpenuhi.

1. Total pendapatan kontrak dapat diukur secara andal.

2. Kemungkinan besar manfaat ekonomis yang berhubungan dengan kontrak tersebut akan mengalir ke perusahaan.

3. Biaya kontrak untuk menyelesaikan kontrak dan tahapan penyelesaian kontrak pada akhir periode pelaporan dapat diukur secara andal.

4. Biaya kontrak yang dapat dibandingkan dengan estimasi sebelumnya.

Menurut Martani $(2015,223)$ salah satu dasar penentuan yang paling populer untuk digunakan yaitu berdasarkan proporsi biaya yang timbul atau cost to cost basis. Caranya adalah persentase penyelesaian pekerjaan kontrak dihitung berdasarkan rasio antara akumulasi biaya yang terjadi dengan total estimasi biaya terakhir untuk penyelesaian kontrak. Formulanya adalah sebagai berikut.

Persentase penyelesaian $=$ Akumulasi Biaya yang Terjadi Sampai Akhir periode 1 Estimasi Total Biaya yang Paling Mutakhir

Persentase penyelesaian tersebut akan menjadi dasar perhitungan berapa total pendapatan dan laba yang diakui sampai akhir periode. Formulanya adalah sebagai berikut.

Akumulasi Pendapatan (atau laba) yang diakui Sampai Akhir Periode $=$ Persentase Penyelesaian x Estimasi Total Pendapatan (atau laba)

Untuk menghitung berapa pendapatan dan laba yang diakui setiap periode, maka perusahaan dapat mengurangkannya dengan total pendapatan atau laba yang sudah diakui sampai periode sebelumnya, seperti ditunjukan pada formula berikut ini.

Pendapatan Periode Berjalan (atau laba) = Akumulasi Pendapatan (atau laba) yang Diakui Sampai Akhir Periode - Estimasi Total Pendapatan (atau laba) yang Sudah Diakui Sampai Periode Sebelumnya

\section{Metode Biaya Terpulihkan (cost-recovery method)}

Menurut Martani $(2016,222)$ dalam beberapa kondisi ketika metode persentase penyelesaian tidak dapat digunakan maka menurut metode ini pendapatan hanya diakui sebesar biaya yang telah terjadi sepanjang biaya tersebut diperkirakan dapat terpulihkan. Ketika semua biaya telah diakui maka laba baru dapat diakui. Perusahaan mengakumulasi biaya kontruksi dalam suatu akun yaitu 
pekerjaan dalam proses (contruction in process), dan mengakumulasi penagihan termin dalam akun kontrak yaitu termin (time billing).

Perusahaan menggunakan metode biaya terpulihkan hanya ketika perusahaan tidak dapat memenuhi kondisi yang disyaratkan untuk menggunakan metode persentase penyelesaian.

Jika kondisi untuk menggunakan metode persentase penyelesaian tidak terpenuhi, maka perusahaan menggunakan metode biaya terpulihkan dalam mengakui pendapatan dan beban kontrak.

\section{METODE PENELITIAN}

Adapun metode yang digunakan dalam penelitian ini adalah metode deskriptif komparatif dengan melakukan uji tabel, dan gambar untuk melihat ada tidaknya pengaruh analisis data dilakukan dengan membandingkan antara percentage of completion method dan cost recovery method berdasarkan PSAK 34 dengan laba kotor perusahaan.

\section{HASIL DAN PEMBAHASAN}

Setelah mempelajari objek-objek yang ada pada perusahaan, bahwa PT Mitra Menara Mandiri tidak selalu menggunakan metode-metode dalam pengakuan pendapatan suatu pekerjaan. Pengakuan pendapatan yang digunakan oleh PT Mitra Menara Mandiri mengakui pendapatannya dengan cara persetujuan antara kedua belah pihak antara pemberi kerja dan penerima kerja, serta kemampuan pemberi kerja dalam melunasi pekerjaan kontraknya. PT Mitra Menara Mandiri dalam menentukan metode apa yang akan digunakan dalam pengakuan pendapatannya dari sisi nilai proyek dan persetujuan terhadap sifat pembayaran yang akan dibayar oleh pemberi kerja, apabila pekerjaan tersebut dibayarkan seluruhnya pada saat pekerjaan telah diselesaikan maka PT Mitra Menara Mandiri menggunakan metode biaya terpulihkan (cost recovery method). Jika proyek tersebut jangka panjang atau disebutkan pada kontraknya secara jelas mekanisme pembayaran yang akan diterima oleh perusahaan dan hak mengenai jasa yang akan disediakan atau diterima oleh kedua belah pihak, maka PT Mitra Menara Mandiri menggunakan metode persentase penyelesaian (percentage of completion method), yaitu pembayarannya berdasarkan persentase yang terletak pada PO (Purchase Order) dan dilakukan 2 sampai 3 kali penagihan sesuai yang telah disepakati.

Kontrak pembangunan yang dikerjakan oleh PT Mitra Menara Mandiri dimulai dengan dibuatnya surat penawaran harga yang di dalamnya berisi nilai kontrak yang harus disepakati oleh perusahaan dan pemberi kerja. Perusahaan juga perlu mempertizmbangkan nilai kontrak yang diberikan oleh pemberi kerja. Pertimbangan khusus yang diperlukan perusahaan untuk menyetujui sebuah nilai kontrak jika kontrak tersebut sudah sesuai dengan standar biaya yang sudah ditetapkan oleh perusahaan maka kontrak tersebut bisa dilaksanakan.

PT Mitra Menara Mandiri menerapkan pengakuan pendapatan pada saat penerimaan kas, sehingga perusahaan mengakui pendapatan pada saat pihak pemberi kerja membayar kas atas penagihan termin yang dilakukan perusahaan. Pendapatan harus diukur dengan nilai wajar imbalan yang diterima atau yang dapat diterima. Jumlah pendapatan yang timbul dari suatu transaksi biasanya 
ditentukan oleh persetujuan antara perusahaan dan pembeli atau pemakai aktiva tersebut.

Proyek-proyek yang dikerjakan oleh PT Mitra Menara Mandiri ada yang tidak berjangka waktu lebih dari satu tahun dan ada yang berjangka lebih daru satu tahun dalam pengerjaannya. Pengakuan pendapatan yang digunakan oleh PT Mitra Menara Mandiri mengakui pendapatannya dengan cara persetujuan antara kedua belah pihak antara pemberi kerja dan penerima kerja, serta kemampuan pemberi kerja dalam melunasi pekerjaan kontraknya. Faktor-faktor yang mempengaruhi PT Mitra Menara Mandiri mengunggapkan pendapatan setiap kontrak pekerjaan yang diterima dengan menggunakan metode persentase penyelesaian (percentage of completion mtehod) atau metode biaya terpulihkan (cost recovery method) sebagai berikut:

1. PT Mitra Menara Mandiri dalam menentukan metode apa yang akan digunakan dalam pengakuan pendapatannya dari sisi nilai proyek dan persetujuan terhadap sifat pembayaran yang akan dibayar oleh pemberi kerja, apabila pekerjaan tersebut dibayarkan seluruhnya pada saat pekerjaan telah diselesaikan maka PT Mitra Menara Mandiri menggunakan metode biaya terpulihkan (cost recovery method). Dan juga PT Mitra Menara Mandiri menggunakan metode biaya terpulihkan hanya ketika perusahaan tidak dapat memenuhi kondisi yang disyaratkan untuk menggunakan metode persentase penyelesaian.

2. Jika proyek tersebut jangka panjang atau disebutkan pada kontraknya secara jelas mekanisme pembayaran yang akan diterima oleh perusahaan dan hak mengenai jasa yang akan disediakan atau diterima oleh kedua belah pihak, maka PT Mitra Menara Mandiri menggunakan metode persentase penyelesaian (percentage of completion method), yaitu pembayarannya dilakukan berkali-kali pada saat penagihan atas pekerjaan yang telah selesai dilaksanakan.

\section{SIMPULAN DAN SARAN}

\section{SIMPULAN}

Berdasarkan hasil penelitian dan evaluasi serta pembahasan yang dilakukan tentang analisis penerapan cost recovery method dan percentage of compleation method berdasarkan PSAK 34 terhadap laba kotor perusahaan PT Mitra Menara Mandiri, maka penulisan dapat memberikan beberapa simpulan sebagai berikut:

1. Perusahaan tidak melakukan pencatatan jurnal pada saat melakukan penagihan termin tetapi perusahaan melakukan pencatatan pada saat uang diterima sehingga tidak terlihat besarnya faktur kontrak yang pernah diajukan.

2. Perusahaan tidak melakukan pencatatan jurnal piutang usaha pada saat menerima pekerjaan dari pemberi kerja dan hanya melakukan pencatatan jurnal pada saat kas diterima.

3. Penetapan pengakuan pendapatan yang diterapkan pada PT Mitra Menara Mandiri belum sesuai dengan prinsip-prinsip akuntansi yang berlaku umum. 


\section{SARAN}

Berkenaan dengan simpulan di atas maka saran yang dapat diberikan adalah sebagai berikut:

1. Pada saat pengajuan termin seharusnya perusahaan melakukan pencatatan dengan mendebit piutang termin dan mengkreditkan pengajuan kemajuan faktur kontrak.

2. Pada saat perusahaan mulai melaksanakan pekerjaan seharusnya perusahaan melakukan pencatatan jurnal piutang usaha pada saat memulai pekerjaan yang pembayarannya dibayarkan pada saat proyek selesai.

\section{DAFTAR PUSAKA}

Martani, D., Siregar, S.V., Wardhani, R., Farahmita, A., Tanujaya, E., Hidayat, T. 2015. Akuntansi Keuangan Menengah. Edisi 4. Salemba Empat. Jakarta.

Lam, N., dan Lau, P. 2015. Akuntansi Keuangan Intermediet Financial Reporting. Edisi 2. Salemba Empat. Jakarta.

Stice Earl K, Stice James D, dkk. 2009. Akuntansi Keuangan Intermediate Accounting. Edisi 16. Salemba Empat. Jakarta.

Diana, A., dan Setiawan, L. 2017. Akuntansi Keuangan Menengah. ANDI. Yogyakarta.

Kieso, D.E., Weygandt, J.J. dan Warfield, T.D. 2008. Akuntansi Intermediate. Edisi 12. Erlangga. Jakarta.

Ikatan Akuntansi Indonesia. 2017. Standar Akuntansi Keuangan. Jakarta : IAI.

Ikatan Akuntansi Indonesia. 2010. Standar Akuntansi Keuangan. Jakarta : IAI.

Nurjanah, E. 2016. Analisis Pengakuan Pendapatan dengan Metode Persentase Penyelesaian Berdasarkan PSAK 34 (Studi Kasus pada PT. X). Skripsi Program Strata 1 Fakultas Ekonomi Universitas Islam Negeri Maulana Malik Ibrahim.

Gustiawan, R. 2013. Analisis Pengakuan Pendapatan pada PT Dimas Cipta Pratama Air Molek. Skripsi Program Strata 1 Fakultas Ekonomi Universitas Islam Negeri Sultan Syarif Qassim Pekanbaru.

Mahtari, S. 2008. Penerapan Standar Akuntansi Keuangan No. 34 Dalam Pengakuan dan Pengukuran Pendapatan Usaha Jasa Konstruksi Pada PT Bintang Angkasa Megantara Medan. Skripsi Program Strata 1 Fakultas Ekonomi Universitas Sumatra Utara. 